\title{
Determination of Copper, Iron, Lead and Zinc in Gasoline by Sequential Multi- Element Flame Atomic Absorption Spectrometry after Solid Phase Extraction
}

\author{
Denilson S. S. Santos, ${ }^{a, b}$ Maria Graças A. Korn, ${ }^{a}$ Mauro A. B. Guida, ${ }^{a}$ \\ Gabriel L. dos Santos, ${ }^{a}$ Valfredo A. Lemos ${ }^{c, d}$ and Leonardo S. G. Teixeira*,a,c \\ ${ }^{a}$ Instituto de Química, Universidade Federal da Bahia, Campus Universitário de Ondina, \\ 40170-290 Salvador-BA, Brazil \\ ${ }^{b}$ Instituto Federal de Educação, Ciência e Tecnologia Baiano, Campus Catu, \\ 48110-000 Catu-BA, Brazil
}

'INCT de Energia e Ambiente, Universidade Federal da Bahia, 40170-280 Salvador-BA, Brazil

${ }^{d}$ Laboratório de Química Analítica, Universidade Estadual do Sudoeste da Bahia, Campus de Jequié, 45206-190 Jequié-BA, Brazil

\begin{abstract}
Desenvolveu-se um procedimento para determinação de cobre, ferro, chumbo e zinco em amostras de gasolina. O procedimento foi baseado na pré-concentração dos metais empregando uma resina modificada com o ácido 3,4-dihidroxibenzóico (XAD-DHB), seguida da dessorção com solução ácida. Os analitos no eluato foram determinados por espectrometria de absorção atômica em chama multielementar sequiencial (FS-FAAS). As amostras de gasolina foram preparadas como microemulsões misturando-se $80 \mathrm{~mL}$ de amostra com $17 \mathrm{~mL}$ de propan-1-ol e $3 \mathrm{~mL}$ de solução tampão (pH 10). As variáveis físico-químicas que influenciam no processo de extração foram otimizadas. Os LODs obtidos foram $2,2 \mu \mathrm{g} \mathrm{L}^{-1}$ para Fe, $3,1 \mu \mathrm{g} \mathrm{L}^{-1}$ para $\mathrm{Cu}, 2,3 \mu \mathrm{g} \mathrm{L}^{-1}$ para $\mathrm{Pb}$, e $2,6 \mu \mathrm{g} \mathrm{L}{ }^{-1}$ para $\mathrm{Zn}$. Os valores de RSDs das concentrações dos analitos nas amostras enriquecidas com 0,05 e $0,1 \mathrm{mg} \mathrm{L}^{-1}$ de cada metal variaram de 5,8 a 9,7\%. As recuperações variaram de 82 a 99\%. O método foi aplicado na determinação dos analitos em níveis de $\mu \mathrm{g} \mathrm{L}^{-1} \mathrm{em}$ amostras de gasolinas coletadas em postos revendedores de Salvador, BA, Brasil.
\end{abstract}

A procedure was developed for determination of copper, iron, lead and zinc in gasoline. The procedure was based on the preconcentration of metals using a resin modified with 3,4-dihydroxybenzoic acid (XAD-DHB), followed by desorption with an acid eluent. The components in the eluate were then determined by fast sequence flame atomic absorption spectrometry (FS-FAAS). The gasoline samples were prepared as microemulsions by mixing $80 \mathrm{~mL}$ of sample with $17 \mathrm{~mL}$ of propan-1-ol and $3 \mathrm{~mL}$ of a buffer solution ( $\mathrm{pH} \mathrm{10).} \mathrm{The} \mathrm{chemical} \mathrm{and}$ physical variables influencing the extraction were optimized. The LODs obtained were $2.2 \mu \mathrm{g} \mathrm{L}^{-1}$ Fe, $3.1 \mu \mathrm{g} \mathrm{L}{ }^{-1} \mathrm{Cu}, 2.3 \mu \mathrm{g} \mathrm{L}^{-1} \mathrm{~Pb}$ and $2.6 \mu \mathrm{g} \mathrm{L}^{-1} \mathrm{Zn}$. The RSDs ranged from 5.8 to $9.7 \%$ in samples spiked with 0.05 and $0.1 \mathrm{mg} \mathrm{L}^{-1}$ of each metal and recoveries varied from 82 to $99 \%$. The procedure was suitable for determination of the analytes at $\mu \mathrm{g} \mathrm{L}^{-1}$ levels in gasoline samples collected from several gas stations in Salvador, State of Bahia, Brazil.

Keywords: preconcentration, metal, gasoline, solid phase extraction, FS-FAAS

\section{Introduction}

Gasoline and diesel engines emit a large amount of pollutants and are major sources of urban air pollution. ${ }^{1}$ Emissions related to automobile fuel combustion contribute significantly to atmospheric pollution, ultimately reducing

*e-mail: 1sgt@ufba.br air quality and negatively affecting human health. The gasoline used as fuel in automobiles may contain metalloids and metallic elements such as $\mathrm{Pb}, \mathrm{Cu}, \mathrm{Zn}, \mathrm{Ni}, \mathrm{Fe}, \mathrm{As}$, $\mathrm{Cd}, \mathrm{Hg}$, Se and Tl. These elements are derived from the raw product, but can also be introduced as additives during production or contaminants during storage. ${ }^{2}$ The presence of such species in gasoline can cause various problems, such as air pollution, fuel degradation, precipitate 
formation, and possible damage of motor parts. In addition, the presence of several metallic species in fuel reduces the efficiency of catalytic reactors in vehicle exhaust systems, thereby increasing the emission of exhaust gases. ${ }^{3-6}$ Among the elements cited, traces of $\mathrm{Cu}, \mathrm{Fe}, \mathrm{Zn}$ are commonly found in gasoline despite not being used as additives. These elements are associated to the fuel degradation and pollution problems mentioned above. Lead compounds, which can be used as an additive because of its ability to increase the octane number, has been banned in several countries due to health problems and pollution associated with its use. Due to these reasons, these four elements were chosen to be investigated in this work.

Flame atomic absorption spectrometry (FAAS) is not sufficiently sensitive for the quantification of trace elements in fuel samples. In addition, the direct introduction of petroleum products may cause instability in the flame. However, in conjunction with a preconcentration step, FAAS methods may prove to be more reliable and accurate for the analysis of fuel samples. One disadvantage of the conventional AAS methods over other techniques, such as ICP OES and ICP-MS, is the longer time required for the determinations, due to their monoelement character. This problem has been solved by the use of sequential atomic spectrometry, which is based on the use of a sweeping monochromator and a computer program for changing the operational conditions of the spectrometer quickly. ${ }^{7,8}$ The purpose of this approach is to increase the sample throughput, in order to determine as many elements as possible, in routine analyses.

Methods involving preconcentration techniques for the quantification of trace elements in different samples, including fuels, are found in the literature..$^{9-12}$ In these procedures, different solid phases have been modified with organofunctional groups to extract metallic species. Possibly, the main problem related to the development and implementation of these procedures in the analysis of automotive fuel is the difficulty in maintaining the organofunctional group attached to the solid phase, due to the leaching action of this type of sample.

Amberlite XAD has been anchored with 3,4-dihydroxybenzoic acid (DHB) through the $-\mathrm{N}=\mathrm{N}-$ group and this combination has been successfully employed for determination of metals in ethanol fuel, ${ }^{12}$ vegetables, ${ }^{13}$ biological, ${ }^{14}$ and other food samples. ${ }^{15}$ Functionalized resins have the advantage of decreasing the leaching of the ligand in preconcentration process. Among other resins that could be used, XAD-DHB was chosen in this work due to prior knowledge of the authors on benefits obtained, such as simplicity of preparation, resistance to medium changes and efficiency in sorption. ${ }^{16}$ In this work, XAD-DHB was used for the preconcentration and determination of copper, iron, lead and zinc in gasoline by fast sequential flame atomic absorption spectrometry (FS-FAAS). The influence of some parameters on the preconcentration was studied and the procedure was applied to the determination of metals in real samples of gasoline.

\section{Experimental}

\section{Apparatus}

A Varian model SpectrAA 220 FS (Mulgrave, Victoria, Australia) flame atomic absorption spectrometer equipped with a deuterium background corrector and an automatic hollow cathode lamp switch was used for absorbance measurements. Iron, copper, lead, and zinc hollow cathode lamps at 248.3, 324.7, 217.0, $213.9 \mathrm{~nm}$, respectively, were run under operational conditions described as follows: lamp current of $5 \mathrm{~mA}$, with exception of copper which used $4 \mathrm{~mA}$ and; spectral resolution of 0.2 and $0.5 \mathrm{~nm}$ for iron and copper respectively, and $1.0 \mathrm{~nm}$ for lead and zinc. The burner height was $13.5 \mathrm{~mm}$. The nebulizer flow rate was $5.0 \mathrm{~mL} \mathrm{~min}{ }^{-1}$, and the flame was composed of acetylene (flow rate $1.5 \mathrm{~L} \mathrm{~min}^{-1}$ ) and air (flow rate $13.5 \mathrm{~L} \mathrm{~min}^{-1}$ ). A Quimis Model Q261 magnetic stirrer was used in the preconcentration procedure, and all $\mathrm{pH}$ measurements were made with a Quimis Model Q400AS pH meter.

\section{Reagents}

All reagents were of analytical grade. Deionized water $(18.0 \mathrm{M} \Omega \mathrm{cm})$ was used to prepare all solutions. Hydrochloric acid solutions were prepared by diluting the concentrated acid Suprapure (Merck, Darmstadt, Germany). Stock solutions of $\mathrm{Cu}, \mathrm{Fe}, \mathrm{Pb}$ or $\mathrm{Zn}\left(1,000 \mathrm{mg} \mathrm{L}^{-1}\right)$ were supplied by Merck. Metal-organic standards (product number WM-21-1X-4, AccuStandard Inc., New Haven, $\mathrm{CT}$, USA) containing $10 \mu \mathrm{g} \mathrm{g}^{-1}$ of $\mathrm{Cu}, \mathrm{Fe}, \mathrm{Pb}$ or $\mathrm{Zn}$ were also used in the procedure. Acetate ( $\mathrm{pH} 4.0-6.0)$, tris-(hydroxymethyl)aminomethane (Tris) (7.0-9.0), and ammonia (10.0) buffers were used in order to adjust the $\mathrm{pH}$ of the metal solutions. The microemulsions were prepared using the solvent propan-1-ol (Merck). Amberlite XAD-2 (Sigma, 20-60 mesh), 3,4-dihydroxybenzoic acid (Sigma), nitric and sulfuric acids (Merck), and sodium nitrite (Reagen) were used in the synthesis of the sorbent.

\section{Extraction device}

A previously described procedure was performed to produce the XAD-DHB resin. ${ }^{15} \mathrm{~A}$ homemade mini-bag was 
prepared by sewing a polypropylene mash with a Nylon line, and filling it with $1 \mathrm{~g}$ of sorbent. A PTFE stem was added to the system with the purpose of supporting the device handles.

\section{Sample preparation}

Gasoline samples were collected randomly from different gas stations in the city of Salvador, State of Bahia, Brazil. Samples were filled into $100 \mathrm{~mL}$ amber glass bottles and stored at $4{ }^{\circ} \mathrm{C}$ to maintain sample integrity until analysis. The bottles were capped and screwed immediately after introduction of the samples. The microemulsions were prepared mixing $80 \mathrm{~mL}$ of gasoline with $3 \mathrm{~mL}$ of buffer solution and $17 \mathrm{~mL}$ of propan-1-ol, which acts as cosolvent, allowing the formation of a homogeneous mixture between the buffer and gasoline. ${ }^{17-19} \mathrm{~A}$ microemulsion was immediately obtained after the manual shaking of the closed bottle. For recovery studies, gasoline samples were spiked with the appropriate volumes of inorganic and organic standards.

\section{Preconcentration and calibration procedures}

The gasoline microemulsion was prepared, as proposed in the upper section, in an erlenmeyer flask with an added solid phase extraction, SPE, device. The system was stirred for $20 \mathrm{~min}$ and the solid phase was dried by air. The desorption step was performed by stirring the preconcentration device with $15 \mathrm{~mL}$ of $0.1 \mathrm{~mol} \mathrm{~L}^{-1} \mathrm{HCl}$ in a polyethylene bottle for $20 \mathrm{~min}$. The flasks were covered during each step. After elution, the SPE device was washed with ethanol to remove possible organic residues. Figure 1 illustrates the entire procedure here proposed.

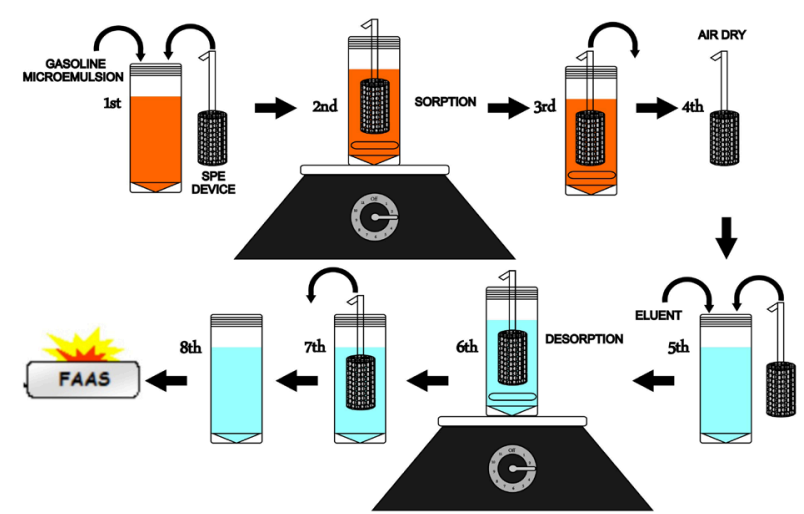

Figure 1. Preconcentration procedure for determination of $\mathrm{Cu}, \mathrm{Fe}, \mathrm{Pb}$ and $\mathrm{Zn}$ in gasoline samples. $1^{\text {st: }}$ : sample microemulsion and SPE device were transferred to a flask; $2^{\text {nd: }}$ the system was stirred for $20 \mathrm{~min} ; 3^{\text {rd }}$ : the solid phase was removed of the flask; $4^{\text {th }}$ : the solid phase was dried by air; $5^{\text {th: }}$ eluent and SPE device were transferred to another flask; $6^{\text {th }}$ : the system was again stirred for $20 \mathrm{~min}$; $7^{\text {th: }}$ the solid phase was removed of the flask; $8^{\text {th: }}$ : the solution obtained was analyzed by FS-FAAS.
Analytical curves were obtained using standards prepared by diluting analyte inorganic stock solutions in $0.1 \mathrm{~mol} \mathrm{~L}^{-1} \mathrm{HCl}$. In order to obtain the preconcentration curve, the standards were transferred to the erlenmeyer flask with the preconcentration device. These systems were then submitted to the preconcentration procedure.

\section{Comparative procedure}

Since no certified reference material is available for trace elements in gasoline, the accuracy was checked by comparison with an independent analytical procedure based in a previous work. ${ }^{20}$ Microemulsion was prepared by mix $3.3 \mathrm{~mL}$ of sample with $6.5 \mathrm{~mL}$ propan-1-ol and $0.1 \mathrm{~mL}$ of $50 \% \mathrm{v} / \mathrm{v} \mathrm{HNO}_{3}$. The analytes were determined by electrothermal atomization atomic absorption spectrometry (ETAAS) using aqueous calibration standards.

\section{Results and Discussion}

\section{Optimization of experimental conditions}

The first procedure tested for the solubilization of buffer solution in the gasoline sample was the preparation of emulsion type water-in-oil using surfactants. For this, the surfactants Triton X-100 and CTAB were used based on previous works. ${ }^{21,22}$ Despite the fact that surfactant-based emulsions result in a lower dilution effect, this procedure require a relatively high amount of surfactant for buffer solubilization in the gasoline sample.

Due to inconveniences related to the surfactant, samples were prepared as microemulsions using propanol as the cosolvent, as described in experimental section. This approach allowed for an effective solubilization of the buffer solution in the sample. After the preconcentration procedure, the eluate was separated and analyzed by FS-FAAS.

The effect of sample $\mathrm{pH}$ on the sorption of $\mathrm{Cu}, \mathrm{Fe}$, $\mathrm{Pb}$, and $\mathrm{Zn}$ by XAD-DHB resin was investigated in a $\mathrm{pH}$ range of 4.0 to 10 and results are shown in Figure 2. The maximum extraction was obtained at $\mathrm{pH} 9$, in agreement with studies on the formation of metal complexes with 3,4-dihydroxybenzoic acid, which is accomplished via deprotonated hydroxyl oxygen atoms whose availability are favored at higher $\mathrm{pH}$ values. ${ }^{23}$ Therefore, the solutions were buffered at $\mathrm{pH} 9$ with a $0.1 \mathrm{~mol} \mathrm{~L}^{-1}$ Tris solution in all subsequent experiments.

The preconcentration times were evaluated from 1 to $40 \mathrm{~min}$ range. The gasoline sample was prepared as a microemulsion spiked with $50 \mu \mathrm{g} \mathrm{L}^{-1}$ of each metal ion. The preconcentration procedure was applied to the sample, which was then eluted with $15 \mathrm{~mL}$ of a $0.1 \mathrm{~mol} \mathrm{~L}^{-1}$ 


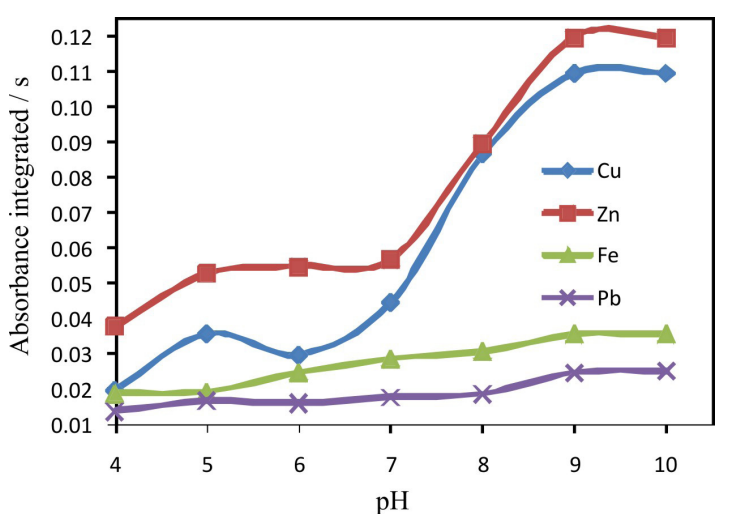

Figure 2. Effect of sample $\mathrm{pH}$ on the sorption of $\mathrm{Cu}, \mathrm{Fe}, \mathrm{Pb}$ and $\mathrm{Zn}$ by XAD-DHB.

hydrochloric acid. The supernatant was separated, and the metals were quantified by FS-FAAS. Since the kinetics of desorption processes are generally faster than those of the sorption processes, the same time was used for both steps to guarantee an efficient elution. According to the results, shown in Figure 3, better responses were obtained with preconcentration and elution times longer than $15 \mathrm{~min}$. Therefore, $20 \mathrm{~min}$ periods were employed for the preconcentration and desorption steps.

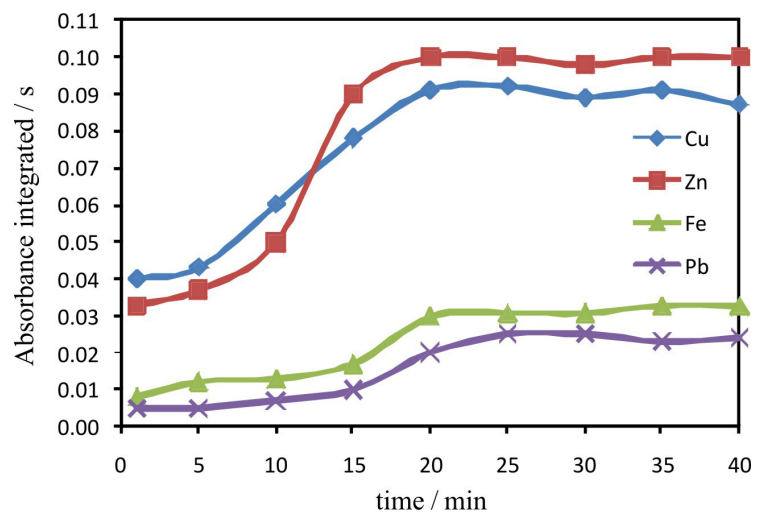

Figure 3. Effect of preconcentration time on the sorption of $\mathrm{Cu}, \mathrm{Fe}, \mathrm{Pb}$ and $\mathrm{Zn}$ by XAD-DHB.

In order to obtain an effective desorption of the metals retained in the solid phase, $\mathrm{HCl}$ solutions from 0.01 to $2.0 \mathrm{~mol} \mathrm{~L}^{-1}$ were evaluated as eluent. The desorption efficiency was evaluated by comparing the results obtained in the analytes determination in the solution resultant of the first elution with those obtained at the second elution and the blank solutions. The solution obtained in the first elution was analyzed by FS-FAAS, and the second elution and blank solutions by ETAAS. At a $95 \%$ confidence level, we concluded that the results obtained for the blank solutions and second elution were not significantly different in terms of the analyte content when $\mathrm{HCl}$ solutions above $0.1 \mathrm{~mol} \mathrm{~L}^{-1}$ were employed as the eluent.
The volume of eluent was also evaluated over a range of 15 to $50 \mathrm{~mL}$. Satisfactory desorptions were obtained with $15 \mathrm{~mL}$ of $0.1 \mathrm{~mol} \mathrm{~L}^{-1} \mathrm{HCl}$ when used in a system spiked with $50 \mu \mathrm{g} \mathrm{L}{ }^{-1}$ of each analyte metal ion, which is a concentration higher than that generally found in gasoline samples. This value was chosen for further analyses.

The microemulsions were prepared mixing $80 \mathrm{~mL}$ of gasoline. Larger sample volumes were not tested because the magnitude of the analytical signal was large enough to allow the quantification, except for $\mathrm{Pb}$, which is commonly present in quantities too low in this type of sample.

\section{Analytical features}

The form of trace elements in petroleum products is not fully known, and different species exhibit distinct sorption behaviors. Therefore, the recovery studies were performed by adding organic and inorganic species of each studied metal. These studies aimed to evaluate the solid phase sorption efficiency of different metal species in gasoline. The recovery percentages obtained for the spiked samples varied from 82 to $99 \%$ (Table 1) and they are comparable with those obtained in previous studies for determination of metals in fuel samples reported in the literature., ${ }^{910}$ Despite these results have shown relatively low recoveries, considering the type of sample and metals concentrations, in routine analysis they could be accepted. In addition, the results show that similar recoveries were obtained for the two forms studied, implying that the XAD-DHB system may be used for the sorption of trace elements in their inorganic or metal-organic forms.

The inorganic standards were chosen for calibration, and the slopes of the calibration curves obtained with and without preconcentration are shown in Table 2. The correlation coefficients (r) of the calibration curves were close to unit within the investigated concentration range. The limit of detection (LOD) of each analyte was calculated as the analyte concentration corresponding to three times the standard deviation for ten consecutive measurements of the blank solution divided by the slope of the calibration curve (Table 2). The precision was calculated from ten consecutive measurements and defined as the relative standard deviation (RSD) of gasoline samples containing 50 and $100 \mu \mathrm{g} \mathrm{L}^{-1}$ of the analytes.

After establishing the conditions of the solid phase extraction procedure, the experimental preconcentration factor $\left(\mathrm{FC}_{\mathrm{Exp}}\right)$ parameter was obtained to evaluate the effects of the preconcentration procedure. The $\mathrm{FC}_{\mathrm{Exp}}$ was calculated as the rate among the angular coefficients of the analytical curves with and without preconcentration. ${ }^{24}$ The results are listed in Table 2. 
Table 1. Determination of $\mathrm{Cu}, \mathrm{Fe}, \mathrm{Pb}$ and $\mathrm{Zn}\left(\mu \mathrm{g} \mathrm{L}^{-1}\right)$ in gasoline samples, and spike recovery tests with standard solutions

\begin{tabular}{|c|c|c|c|c|c|c|c|c|c|c|c|c|c|c|c|c|}
\hline \multirow{3}{*}{ Sample } & \multicolumn{4}{|c|}{$\mathrm{Cu}$} & \multicolumn{4}{|c|}{$\mathrm{Fe}$} & \multicolumn{4}{|c|}{$\mathrm{Pb}$} & \multicolumn{4}{|c|}{$\mathrm{Zn}$} \\
\hline & \multicolumn{3}{|c|}{ Content $\left(\mu \mathrm{g} \mathrm{L}^{-1}\right)$} & \multirow{2}{*}{$\begin{array}{l}\mathrm{R} \\
(\%)\end{array}$} & \multicolumn{3}{|c|}{ Content $\left(\mu \mathrm{g} \mathrm{L}^{-1}\right)$} & \multirow{2}{*}{$\begin{array}{l}\mathrm{R} \\
(\%)\end{array}$} & \multicolumn{3}{|c|}{ Content $\left(\mu \mathrm{g} \mathrm{L}^{-1}\right)$} & \multirow{2}{*}{$\begin{array}{r}-\mathrm{R} \\
(\%)\end{array}$} & \multicolumn{3}{|c|}{ Content $\left(\mu \mathrm{g} \mathrm{L}^{-1}\right)$} & \multirow{2}{*}{$\begin{array}{l}\mathrm{R} \\
(\%)\end{array}$} \\
\hline & $\begin{array}{r}\text { Without } \\
\text { addition }\end{array}$ & Added & Found & & $\begin{array}{l}\text { Without } \\
\text { addition }\end{array}$ & Added & Found & & $\begin{array}{l}\text { Without } \\
\text { addition }\end{array}$ & Added & Found & & $\begin{array}{l}\text { Without } \\
\text { addition }\end{array}$ & Added & Found & \\
\hline \multirow[t]{3}{*}{ (SSI) } & $17 \pm 1$ & 50 & $62 \pm 2$ & 94 & $8 \pm 1$ & 50 & $54 \pm 1$ & 94 & $8 \pm 0.2$ & 50 & $53 \pm 1$ & 92 & $10 \pm 0.3$ & 50 & $54 \pm 4$ & 91 \\
\hline & & 100 & $95 \pm 3$ & 82 & & 100 & $94 \pm 6$ & 87 & & 100 & $90 \pm 4$ & 89 & & 100 & $98 \pm 3$ & 90 \\
\hline & & 200 & $193 \pm 1$ & 89 & & 200 & $183 \pm 12$ & 88 & & 200 & $181 \pm 4$ & 90 & & 200 & $192 \pm 1$ & 92 \\
\hline \multirow[t]{3}{*}{ (SSO) } & $13 \pm 1$ & 50 & $57 \pm 1$ & 90 & $20 \pm 1$ & 50 & $63 \pm 3$ & 89 & $10 \pm 1$ & 50 & $52 \pm 5$ & 87 & $10 \pm 1$ & 50 & $54 \pm 3$ & 90 \\
\hline & & 100 & $103 \pm 3$ & 91 & & 100 & $114 \pm 9$ & 94 & & 100 & $96 \pm 6$ & 87 & & 100 & $109 \pm 8$ & 99 \\
\hline & & 200 & $189 \pm 1$ & 90 & & 200 & $211 \pm 15$ & 96 & & 200 & $181 \pm 12$ & 86 & & 200 & $187 \pm 11$ & 89 \\
\hline
\end{tabular}

(SSI): sample spiked with inorganic standard; (SSO): sample spiked with metallo-organic standard; R: recovery.

Table 2. Figures of merit for the proposed procedure

\begin{tabular}{|c|c|c|c|c|c|c|}
\hline \multirow{2}{*}{ Analyte } & \multirow{2}{*}{$\begin{array}{l}\mathrm{LOD} \\
\mu \mathrm{g} \mathrm{L}^{-1}\end{array}$} & \multicolumn{2}{|c|}{ Slope of calibration curves $\mathrm{L} \mathrm{mg}^{-1}$} & \multicolumn{2}{|c|}{$(\mathrm{RSD}) \%$} & \multirow[b]{2}{*}{$\mathrm{CF}_{\mathrm{Ex}}$} \\
\hline & & conventional & preconcentration & $0.05 \mathrm{mg} \mathrm{L}^{-1}$ & $0.1 \mathrm{mg} \mathrm{L}^{-1}$ & \\
\hline$\overline{\mathrm{Cu}}$ & 3.1 & 0.13 & 0.70 & 7.7 & 8.3 & 5.4 \\
\hline $\mathrm{Fe}$ & 2.2 & 0.09 & 0.48 & 9.7 & 9.3 & 5.3 \\
\hline $\mathrm{Pb}$ & 2.3 & 0.03 & 0.20 & 8.0 & 9.7 & 6.7 \\
\hline $\mathrm{Zn}$ & 2.6 & 0.23 & 1.4 & 6.4 & 5.8 & 6.1 \\
\hline
\end{tabular}

LOD: Limit of detection, RSD: relative standard deviation, $\mathrm{CF}_{\mathrm{Exp}}$ : experimental preconcentration factor.

The accuracy of the proposed procedure was evaluated by comparing the results with those obtained using a procedure previously described. ${ }^{20}$ The concentration values obtained by the proposed procedure showed negative biases when they were compared with the comparative method (Table 3). These results are consistent with the recovery study that showed values minor than $100 \%$. However, errors were lower than $10 \%$, indicating the good analytical performance of the proposed procedure for analysis of real samples.

The proposed procedure uses a relatively small amount of reagents, therefore reducing the generated waste and decreasing the analysis costs when compared to conventional preconcentration procedures based on batch strategies. Low concentrations of elements can be detected using practical sample volumes. In addition, the proposed procedure is advantageous because it has shown good perspectives of being applied to inorganic and organic solutions, as we have obtained favorable recoveries for both chemical forms. Other advantage is that retaining the solid phase inside the mini-bag allows eliminating the filtration step, and consequently, increases the analytical frequency and minimizes the risks of contamination due to excessive manipulation. The proposed SPE device displayed a strong resistance to attack by the organic sample or hydrochloric acid, showing good capacity of retention.

\section{Analytical application}

The developed procedure was applied for determination of $\mathrm{Cu}, \mathrm{Fe}, \mathrm{Pb}$ and $\mathrm{Zn}$ in commercial gasoline samples collected from different gas stations in Salvador. As previously mentioned, the samples were collected in glass bottles and stored at $4{ }^{\circ} \mathrm{C}$, conducted at the laboratory and immediately prepared as microemulsions to stabilize the sample. Results are shown in Table 4. All experiments were made in triplicate.

Table 3. Determination of $\mathrm{Cu}, \mathrm{Fe}, \mathrm{Pb}$ and $\mathrm{Zn}\left(\mu \mathrm{g} \mathrm{L}^{-1}\right)$ in gasoline samples by the proposed procedure (FS-FAAS) and the comparative one (ETAAS)

\begin{tabular}{lcccccccc}
\hline \multirow{2}{*}{ Sample } & \multicolumn{2}{c}{$\mathrm{Cu}$} & \multicolumn{2}{c}{$\mathrm{Fe}$} & \multicolumn{2}{c}{$\mathrm{Pb}$} & \multicolumn{2}{c}{$\mathrm{n}$} \\
& FS-FAAS & ETAAS & FS-FAAS & ETAAS & FS-FAAS & ETAAS & FS-FAAS & ETAAS \\
\hline 1 & $16.6 \pm 0.2$ & $17.1 \pm 0.3$ & $13.3 \pm 0.3$ & $13.6 \pm 0.2$ & $<2.3$ & $<3.6$ & $7.3 \pm 0.2$ & $7.6 \pm 0.4$ \\
2 & $10.1 \pm 0.2$ & $10.8 \pm 0.4$ & $37.4 \pm 0.3$ & $38.1 \pm 0.3$ & $3.3 \pm 0.1$ & $<3.6$ & $16.1 \pm 0.2$ & $16.8 \pm 0.4$ \\
3 & $13.0 \pm 0.3$ & $13.6 \pm 0.3$ & $24.7 \pm 0.2$ & $25.3 \pm 0.2$ & $<2.3$ & $<3.6$ & $5.1 \pm 0.2$ & $5.6 \pm 0.5$ \\
\hline
\end{tabular}

Mean \pm s.d. ( $n=3,95 \%$ confidence level). 
Table 4. Determination of $\mathrm{Cu}, \mathrm{Fe}, \mathrm{Pb}$ and $\mathrm{Zn}$ in three commercial gasoline samples by the proposed procedure $(n=3,95 \%$ confidence level)

\begin{tabular}{lcccc}
\hline \multirow{2}{*}{ Sample } & \multicolumn{4}{c}{ Amount of metal $\left(\mu \mathrm{g} \mathrm{L}^{-1}\right)$} \\
& $\mathrm{Cu}$ & $\mathrm{Fe}$ & $\mathrm{Pb}$ & $\mathrm{Zn}$ \\
\hline 4 & $10.9 \pm 0.9$ & $15.0 \pm 0.5$ & $<2.3$ & $10.4 \pm 0.1$ \\
5 & $14.8 \pm 0.3$ & $13.5 \pm 0.6$ & $<2.3$ & $3.5 \pm 0.2$ \\
6 & $8.8 \pm 0.3$ & $22.4 \pm 1.9$ & $8.0 \pm 0.1$ & $9.0 \pm 0.1$ \\
\hline
\end{tabular}

\section{Conclusions}

The accurate determination of trace metals in petroleum products is important. Herein, we propose a procedure for determination of $\mathrm{Cu}, \mathrm{Fe}, \mathrm{Pb}$ and $\mathrm{Zn}$ in gasoline samples using FS-FAAS after a preconcentration procedure using XAD-2 resin, chemically modified with the chelating agent DHB. The procedure is simple and does not require the sample to be subjected to any harsh or time-consuming treatments with concentrated acids or long heating times, therefore minimizing the risk of contamination or losses. The sorbent XAD-DHB remains confined in the SPE device, eliminating the need of a filtration step, therefore reducing risks associated with excessive handling. The simplicity, versatility and sample throughput using the proposed procedure were improved in comparison with similar procedures based on batch strategies.

\section{Acknowledgments}

The authors would like to acknowledge the financial support received from CNPq, FINEP and FAPESB.

\section{References}

1. Dan, Y.; Dengshan, G.; Gang, Y.; Xianglin, S.; Fan, G; J. Hazard. Mater. 2005, B127, 149.

2. Ozaki, H.; Watanabe, I.; Kuno, K.; Water, Air, Soil Pollut. 2004, 157, 209.

3. Falahi-Ardakani, A.; Ecotoxicol. Environ. Saf. 1984, 8, 152.

4. Ligero, R. A.; Casas-Ruiza, M.; Barrera, M.; López-Aguayo, F.; Sales, D.; García, D.; Environ. Int. 2004, 3, 99.

5. Pereira, R. C. C.; Pasa, V. M. D.; Energy Fuels 2005, 19, 426.

6. Teixeira, L. S. G.; Souza, J. C.; dos Santos, H. C.; Pontes, L. A. M.; Guimarães, P. R. B.; Sobrinho, E. V.; Vianna, R. F.; Fuel Process. Technol. 2007, 88, 73.
7. Amorim, F. A. C.; Ferreira, S. L. C.; Talanta 2005, 65, 960.

8. Projahn, H. D.; Steeg, U.; Sanders, J.; Vanclay, E.; Anal. Bioanal. Chem. 2004, 378, 1083.

9. Roldan, P. S.; Alcântara, I. L.; Padilha, C. C. F.; Padilha, P. M.; Fuel 2005, 84, 305.

10. Dias Filho, N. L.; Gushikem, Y.; Polito, W. L.; Moreira, J. C.; Ehirim, E. O.; Talanta 1995, 42, 1625.

11. Teixeira, L. S. G.; Rocha, R. B. S.; Sobrinho, E. V.; Guimarães, P. R. B.; Pontes, L. A. M.; Teixeira, J. S. R.; Talanta 2007, 72, 1073.

12. Teixeira, L. S. G.; Bezerra, M. A.; Lemos, V. A.; dos Santos, H. C.; de Jesus, D. S.; Costa, A. C. S.; Sep. Sci. Technol. 2005, 40, 2555.

13. Bezerra, M. A.; Santos, W. N. L.; Lemos, V. A.; Korn, M. G. A.; Ferreira, S. L. C.; J. Hazard. Mater. 2007, 148, 334.

14. Lemos, V. A.; Bezerra, M. A.; Amorim, F. A. C.; J. Hazard. Mater. 2008, 157, 613.

15. Lemos, V. A.; Baliza, P. X.; Yamaki, R. T.; Rocha, M. E.; Alves, A. P. O.; Talanta 2003, 61,675.

16. Lemos, V. A.; Baliza, P. X.; Santos, J. S.; Nunes, L. S.; de Jesus, A. A.; Rocha, M. E.; Talanta 2005, 66, 174.

17. Brandão, G. P.; Campos, R. C.; Castro, E. V. R.; Jesus, H. C.; Spectrochim. Acta, Part B 2008, 63, 880.

18. Brandão, G. P.; Campos, R. C.; Luna, A. S.; Spectrochim. Acta, Part B 2005, 60, 625.

19. Souza, R. M.; Meliande, A. L. S.; Silveira, C. L. P.; Aucélio, R. Q.; Microchem. J. 2006, 82, 281137.

20. Reyes, M. N. M.; Campos, R. C.; Spectrochim. Acta, Part B 2005, 60, 615 .

21. Santos, D. S. S.; Korn, M. G. A.; Teixeira, A. P.; Barbosa, J. T. P.; Ferreira, S. L. C.; Teixeira, L. S. G.; Spectrochim. Acta, Part B 2007, 62, 1072.

22. Saint'Pierre, T. D.; Dias, L. F.; Maia, S. M.; Curtius, A. J.; Spectrochim. Acta, Part B 2004, 59, 551.

23. Griffith, W. P.; Nogueira, H. S.; Parkin, B. C.; Sheppard, R. N.; White, A. J. P.; Williams, D. J.; J. Chem. Soc. Dalton Trans. 1995, $1,1775$.

24. Stalikas, C. D.; Trends Anal. Chem. 2003, 21, 343.

Submitted: April 19, 2010 Published online: November 16, 2010 